\title{
PELATIHAN DAN PENDAMPINGAN PEMANFAATAN LIMBAH KAIN PERCA BAGI PELAKU UMKM BERKAH COLECTION DI BIBIS LUHUR
}

\author{
Cahyani Tunggal Sari ${ }^{1)}$ Yofhi Septian $\mathbf{P}^{2)}$ Tri Nurdyastuti ${ }^{3)}$ \\ ${ }^{12)}$ Program studi Manajemen, ${ }^{3)}$ program studi D3 akuntansi STIE AUB Surakarta \\ Email: Yofhi_Septian@yahoo.com
}

\begin{abstract}
Abstrak
Berkah colection merupakan salah satu UMKM beralamat di Bibis Luhur kelurahan Nusukan kecamatan Banjarsari kota Surakarta. Kegiatan utama dari Berkah Colection adalah pembuatan pakain dewasa wanita, dari kegiatan pembuatan pakaian tersebut muncul limah dari sisa kain yang tidak terpakai yang disebut kain perca. Guna mengatasi permalahan tersebut Tim pegabdian berupaya untuk memberikan solusi agar limbah kain perca yang awalnya hanya menumpuk sebagai sampah dapat di manfaatkan menjadi barang/benda yang mempunyai nilai jual.

Salah satu pemanfaatan limbah kain perca yaitu dengan membuat dompet kain/ pouch yang dapat digunakansebagai tempat menyimpan uang, handphone dan kosmetik ketika bepergian.Selain mempunyai nilai tambah diharapkan pembuatan dompet kain/ pouch dapat memberikan tambahan penghasilan bagi Berkah colection.

Tim pengabdian kepada masyarakat tertarik untuk membuat kegiatan pengabdian dengan judul "Pelatihan dan Pendampingan Pemanfaatan Limbah Kain Perca Bagi Pelaku UMKM Berkah Colection Di Bibis Luhur Kelurahan Nusukan Kecamatan Banjarsari Surakarta.“

Kata kunci : UMKM, Limbah kain perca.
\end{abstract}

\section{PENDAHULUAN}

UMKM (Usaha Mikro, Kecil, Menengah) sebagai pengerak perekonomian berperan sangat besar bagi kemajuan perekonomian Indonesia. UUD yang mengatur tentang UMKM adalah Undang - Undang No 20 Tahun 2008 yang salah satu isinya bahwa pemerintah pusat dan pemerintah daerah memfasilitasi pengembang usaha dengan cara memberikan intensif kepada usaha mikro, kecil, dan menengah, mengembangkan teknologi dan kelestarian lingkungan hidup.

Berkah colection merupakan salah satu UMKM beralamat di Bibis Luhur kelurahan Nusukan kecamatan Banjarsari kota Surakarta. Kegiatan utama dari Berkah Colection adalah pembuatan pakaian dewasa wanita, dari kegiatan pembuatan pakaian tersebut muncul limbah dari sisa kain yang tidak terpakai yang disebut kain perca. Guna mengatasi permalahan tersebut Tim pegabdian berupaya untuk memberikan solusi agar limbah kain perca yang awalnya hanya menumpuk sebagai sampah dapat di manfaatkan menjadi barang/benda yang mempunyai nilai jual.

Salah satu pemanfaatan limbah kain perca yaitu dengan membuat dompet kain/ pouch yang dapat digunakansebagai tempat menyimpan uang, handphone dan kosmetik ketika bepergian.Selain mempunyai nilai tambah diharapkan pembuatan dompet kain/ pouch dapat memberikan tambahan penghasilan bagi Berkah colection.

\section{METODE}

Kegiatan Pengabdian Kepada Masyarakat ini berbentuk ceramah, simulasi dan diskusi kepada kelompok UMKM dengan tujuan memberikan edukasi kepada pelaku UMKM akan pentingnya menumbuhkan kesadaran pemanfaatan libah kain perca dan manfaat yang akan mereka peroleh.

\section{HASIL DAN PEMBAHASAN}

Pada pembahasan ini disajikan analisis hasil pengolahan data dari hasil pretest dan posttest yang dilakukan tim pada saat pengabdian. Analisis dilakukan dengan menggunakan uji beda untuk mengetahui 
WASANA NYATA : Jurnal Pengabdian kepada Masyarakat ISSN : $\underline{\mathbf{2 5 8 0 - 8 4 4 3}}$

Vol.4, No.1 April (2020); p.14-16; https://e-journal.stie-aub.ac.id/index.php/wasana_nyata

apakah terdapat perbedaan pemahaman tentang materi yang diberikan sebelum pelatihan dan sesudah pelatihan. Hasil analisis data sebagai berikut:

Tabel IV.1

Hasil Analisis Data

Paired Samples Statistics

\begin{tabular}{|c|c|c|c|c|c|}
\hline & & Mean & $\mathrm{N}$ & Std. Deviation & $\begin{array}{l}\text { Std. Error } \\
\text { Mean }\end{array}$ \\
\hline Pair & Pretest & 52,0000 & 5 & 5,70088 & 2,54951 \\
\hline 1 & Posttest & 80,0000 & 5 & 3,53553 & 1,58114 \\
\hline
\end{tabular}

Dari hasil diatas menunjukkan bahwa rata-rata pemahaman terhadap materi sebelum dan sesudah dilakukan pelatihan pada peserta. Sebelum pelatihan rata-rata pemahaman terhadap materi dari 5 orang peserta adalah sebesar 52, sementara setelah diberikan pelatihan rata-rata pemahaman peserta sebesar 80 .

Tabel IV.1

Hasil Analisis Data

Paired Samples Test

\begin{tabular}{|c|c|c|c|c|c|c|c|c|}
\hline & \multicolumn{5}{|c|}{ Paired Differences } & \multirow[b]{3}{*}{$\mathrm{t}$} & \multirow[b]{3}{*}{ df } & \multirow[b]{3}{*}{ Sig. (2-tailed) } \\
\hline & \multirow[b]{2}{*}{ Mean } & \multirow[b]{2}{*}{ Std. Deviation } & \multirow{2}{*}{$\begin{array}{c}\text { Std. Error } \\
\text { Mean }\end{array}$} & \multicolumn{2}{|c|}{$\begin{array}{l}95 \% \text { Confidence } \\
\text { Interval of the } \\
\text { Difference }\end{array}$} & & & \\
\hline & & & & Lower & Upper & & & \\
\hline Pair 1 Pretest - Posttest & $-28,00000$ & 5,70088 & 2,54951 & $-35,07857$ & $-20,92143$ & $-10,983$ & 4 &, 000 \\
\hline
\end{tabular}

Nilai t hitung sebesar $-10,983$ dengan sig $0.000<0.05$, artinya rata-rata pemahaman sebelum dan sesudah pelatihan dan pendampingan terhadap peserta terdapat perbedaan. Dengan demikian dapat dinyatakan bahwa penyampaian materi dan pelatihan sangat mempengaruhi pemahaman peserta pelatihan.

\begin{tabular}{|l|l|}
\hline $\begin{array}{l}\text { Belum ada kesadaran tentang } \\
\text { pemanfaatan limbah kain } \\
\text { perca }\end{array}$ \\
\begin{tabular}{|l|l|} 
Belum ada keterampilan \\
pemanfaatan limbah kain \\
perca menjadi dompet / pouch
\end{tabular} \\
$\begin{array}{l}\text { Belum ada penghasilan } \\
\text { tambahan dari pemanfaatan } \\
\text { limbah kain perca. }\end{array}$
\end{tabular}

Berdasarkan hasil dan pembahasan kegiatan pengabdian kepada masyarakat yang telah diuraikan sebelumnya, dapat disimpulkan bahwa :

1. Kesadaran pelaku UMKM khususnya Berkah Colection dalam pemanfaatan limbah kain perca mulai tumbuh. 
WASANA NYATA : Jurnal Pengabdian kepada Masyarakat ISSN : $\underline{\mathbf{2 5 8 0 - 8 4 4 3}}$

Vol.4, No.1 April (2020); p.14-16; https://le-journal.stie-aub.ac.id/index.php/wasana_nyata

2. Pelaku UMKM mempunyai keterampilan baru pemanfaatan limbah kain perca menjadi dompet/pouch.

3. Harapan adanya penghasilan tambahan pelaku UMKM khususnya Berkah Colection dengan memanfaatkan limbah kain perca meningkat seiring diminatinya produk.

\section{SARAN}

Penyelenggaraan program pengabdian kepada masyarakat dengan bentuk Pelatihan dan Pendampingan Pemanfaatan Limbah Kain Perca Bagi Pelaku UMKM Berkah Colection Di Bibis Luhur Kelurahan Nusukan Kecamatan Banjarsari Surakarta diharapkan kegiatan seperti dapat dilakukan secara berkesinambungan dan berlanjut pada strategi menemukan keunikan produk.

\section{UCAPAN TERIMAKASIH}

Ucapan terimakasih disampaikan kepada Ibu-Ibu Pembinaan Kesejahteraan Keluarga Kelurahan Nusukan, Kecamatan Banjarsari Surakarta.

\section{DAFTAR PUSTAKA}

Anggraeni dan Ainul Hayat (2014). Pengembangan Usaha Mikro, Kecil, Dan Menengah (Umkm). Jurnal Administrasi Publik (JAP), Vol. 1, No. 6, Hal. 1286-1295

https://judulindo.blogspot.com/2017/04/cara-membuat-pouch-dompet-dari-kain.html diakses pada 21 Maret 2019 pukul 21.00

Undang-undang Nomor 20 Tahun 2008 tentang Usaha Mikro, Kecil, dan Menengah.

https://www.hipwee.com/tips/biar-kain-perca-ngga-terbuang-sia-sia-5-kreasi-tak-biasa-ini-bisa-kamucoba/

https://judulindo.blogspot.com/2017/04/cara-membuat-pouch-dompet-dari-kain.html 